\title{
Effect of Teachers' Corrective Feedback on Learners' Oral Accuracy in English Speaking Lessons
}

\author{
Huong Thanh Nhac \\ Hanoi Law University, Ha Noi city, Vietnam \\ https://orcid.org/0000-0003-0185-529X
}

\begin{abstract}
Corrective feedback plays a vital role in contributing to the success of English language teaching and learning at all levels owing to its essential functions in developing learners' English capacity. However, the ongoing debate on how effective corrective feedback is still remains controversial among educational scholars. This empirical study examined the effects of teachers' corrective feedback on learners' English oral accuracy at a higher education institution. The study used a before-and-after approach with the involvement of 47 law major sophomores at lower intermediate level who were divided into control and experimental groups. Specifically, the experimental group included two batches, including 16 participants companions receiving the explicit correction and metalinguistic feedback, and 15 learners provided with recast and clarification requests. In addition, there were 16 participants in the control group who were given no form of corrective feedback during English speaking lessons. The results indicate that the efficacy of corrective feedback is clearly acknowledged thanks to the contrastive analysis of the outcome in the learners' performance on the post-tests. In particular, the results of the explicit corrective feedback slightly outweighed the results of the control group receiving implicit feedback in terms of improving learners' accurate usage of grammar, vocabulary, and pronunciation. The findings emphasise the importance of teachers' corrective feedback in helping students improve their English competency.
\end{abstract}

Keywords: accuracy; corrective feedback; effects; speaking English lesson

\section{Introduction}

Recently, the teaching methodology focus has changed from being grammarbased to communicative teaching, which promotes learners' fluency. Specifically, the former method highlights linguistic aspects, including phonological, lexical and grammatical features, while the latter focuses on 
language functional patterns and communicative competence theory (Ellis, 2003). Therefore, learners are encouraged to focus on meaning rather than form (Savignon, 2006). In such a context, corrective feedback (CF), either in written or oral form, proves to play an indispensable role in foreign language teaching and learning owing to its crucial role in facilitating learner's language development (Li \& Vuono, 2019).

In the literature, there has been some polarisation of thought regarding the impact of CF on learners' second language (L2) or foreign language (FL) acquisition process, leading to different or even contradicting theories as the effectiveness of CF differs according to classroom contexts (Li \& Iwashita, 2021; Lyster et al., 2013). Nevertheless, proponents of CF affirm that CF is of great importance in teaching and learning in different L2 classrooms (Ha \& Murray, 2021; Lyster et al. 2013) as it can enable students to be aware of the gap between their interlanguage forms and the target language forms. This helps them to restructure the interlanguage grammar and initiates the learning process. While consensus has been reached regarding the effectiveness of CF on students' L2 acquisition, the debate around whether explicit or implicit CF is more effective has gained little agreement among scholars. Most of the studies conducted in L2 classroom contexts have consistently indicated that recasts are the most frequently used $\mathrm{CF}$ by teachers but prompts are superior to recasts in eliciting more immediate learner uptake (Ammar \& Spada, 2006; Ellis et al., 2006; Brown, 2016; Wang \& Li, 2020). Conversely, Ellis et al. (2006) compare implicit (recasts) and explicit (metalinguistic prompt) feedback and find that the explicit metalinguistic prompt group performs better than the implicit recast group. However, comparing only the two feedback types does not clarify which is more associated with L2 development, explicitness (metalinguistic information), or opportunities for learners to reformulate their output. One solution to overcome this limitation is the addition of an explicit correction group that is given metalinguistic information and input. Regarding accuracy in speaking, according to Chehr Azad et al. (2017), learners' specific spoken accuracy is able to be improved with the provision of $\mathrm{CF}$.

In the tertiary context of Vietnam, CF seems to be attractive to researchers. The majority of the research focuses on learners and teachers' belief in the importance, types and timing of oral corrective feedback (Ha, 2017; Ha et al., 2021; Ha \& Murray, 2020; Ha \& Nguyen, 2020; Tran \& Cang, 2020), the role of CF in students' learning (Le, 2014; Pham \& Iwashita, 2018; Dam, 2018) or the patterns of CF (Pham \& Pham, 2018). Despite the efforts made by the researcher, it was difficult to identify documented experimental studies which were conducted on Vietnamese university EFL students on the effectiveness of teachers' CF on learners' speaking accuracy. This motivated the present study, which is a follow-up on an observational study on the patterns of teachers' $\mathrm{CF}$ and learners' uptake previously conducted in a law school context.

For these reasons, this study is a modest attempt to contribute to the common knowledge of the impact of explicit CF including explicit correction, metalinguistic and implicit $\mathrm{CF}$ in the form of recasts and clarification requests on 
learners' oral accuracy. Three research questions are formulated to address the above issue:

1. Do metalinguistic feedback and explicit correction significantly affect learners' accuracy in English speaking lessons?

2. Do recasts and clarification requests significantly affect learners' accuracy in English speaking lessons?

3. Is there any significant difference in the effects of two types of CF in two experimental groups?

\section{Literature Review}

\subsection{Oral Accuracy}

According to language researchers, accuracy, complexity and fluency are three important components of achieving L2 proficiency (Ellis \& Barkhuizen, 2005). The key aspect of speaking in this current study is accuracy. Ellis (2003, p.339) defines accuracy as "the extent to which the language produced in performing a task conforms to the target language norms". Housen and Kuiken (2009, p. 466) refer to accuracy as "error-free" speech. Oral accuracy is therefore measured by the accurate use of different aspects of the target language.

Gower et al. (2005) affirm that accuracy includes the correct usage of every component, that is, vocabulary, grammar, and pronunciation. If a speaker uses one language that is not as accurate as the way a native speaker does, he or she is said to lack language accuracy. In other words, to achieve accuracy, learners are expected to make few language errors in the process of producing the target language.

Grammar or grammatical items refer to the set of rules by means of which words and phrases are connected to produce the target language. Language grammar is also concerned with the rules of syntax (such as verb tenses and subject-verb agreement) (Tesnim, 2019).

Vocabulary or lexical resource is defined as a learner's use of language to express meaning. As commonly known, a 'lexeme', or lexical item, the smallest unit of a language, may be formed either as one word ('look'), or by using a suffix ('-s'), or a prefix ('ex-'). Moreover, the lexical resource covers the understanding and use of compound words and idioms as used by learners (Tesnim, 2019).

Furthermore, pronunciation refers to how words are pronounced. Broadly speaking, pronunciation is understood as the way in which sound or a group of sounds is produced. Pronunciation also includes the intonation, rhythm, emphasis, and pauses of the speaker's utterance (Tesnim, 2019). This study focuses on the learners' oral accuracy in English lessons; thus, grammar, vocabulary and pronunciation are three main criteria in examining the efficacy of CF.

\subsection{Corrective Feedback}

One of the main roles of the language teacher is to give corrective feedback to students' work containing errors. CF has been defined and classified in different 
dimensions denoting the understanding of and interest in CF in L2 research (Brown, 2014). Lightbown and Spada (2003, p.172) define CF as "any indication to a learner that his/her use of the target language is incorrect". Specifically, CF includes various responses following learners' erroneous utterances. Likewise, Ellis et al. (2006) indicated that $\mathrm{CF}$, acting as a form-focusing device, refers to responses to learners' errors. The responses "can consist of (a) and indication that an error has been committed; (b) the provision of the correct target language form; or (c) metalinguistic information about the nature of the error; or any combination of these" (Ellis et al., 2006, p.340). Put simply, CF is the process of providing correction by teachers for students' errors, either in the written form (such as teachers' written feedback on learners' assignments or oral form (such as teachers' spoken responses to learners' spoken errors). It can be seen that both modes of CF have been viewed to be effective for learners to reformulate correct target language (Li \& Vuono, 2019). In the scope of this research, only oral CF was investigated, therefore $\mathrm{CF}$ in this article refers to $\mathrm{CF}$ for spoken errors.

Lyster and Mori (2006) identified six different types of CF, namely recast, explicit correction, clarification request, metalinguistic feedback, elicitation and repetition. Sheen (2011) classified oral CF strategies into two subcategories, one of which includes the CF providing the correct form, namely recasts and explicit correction. The other four feedback types are called prompts in the sense that correct forms are withheld and students are provided with clues to generate corrections ( $\mathrm{Li}, 2014)$.

\subsection{Corrective Feedback in L2 and FL Acquisition}

According to Lyster et al. (2013, p.31), CF in relation to linguistic focus is "an especially promising topic for further investigation". While a variety of empirical studies have been conducted to clarify the efficiency of CF in L2 and FL acquisition, the debate over what types of CF are more effective still remains a contested topic among educators. Among different types of $\mathrm{CF}$, the explicit $\mathrm{CF}$ includes explicit correction and metalinguistic feedback while recast and clarification request are viewed as being implicit. On the one hand, a number of studies reveal the positive impacts of explicit CF outweigh those of implicit ones. Ellis et al. (2006) demonstrate that learners provided with metalinguistic feedback perform much better than those supplied with recasts in a delayed post-test; however, the immediate post-test results of the two groups show little difference. Similarly, Tavakoli and Zarrinabadi (2016) found that implicit CF does not influence L2 speakers' willingness to communicate in English whereas explicit CF does by promoting their L2 self-confidence. Dabaghi and Basturkmen (2009) compare the effectiveness of explicit and implicit CF in morphological and syntactical features. The results indicate that explicit CF is clearly more effective than implicit CF. Moreover, explicit CF is more effective for morphological features in comparison with syntactical ones.

On the other hand, various studies indicate that implicit CF would improve learners' language accuracy more effectively than direct $\mathrm{CF}$ in the long term (Mujtaba et al., 2020; Baleghizadeh \& Dadashi, 2011; Hosseiny, 2014). Concerning the implicit $\mathrm{CF}$, recasts are able to equip learners with both comprehensible input and focus on form (Leeman, 2003). However, an important aspect is that the use of recast depends on the linguistic features. 
Recasts are said not to be useful for non-salient, hard linguistic structures (Lyster \& Mori, 2006), yet exert a significant influence on salient, transparent structures (Ammar \& Spada, 2006). Like recasts, clarification requests belong to implicit CF. Yet they are unlike recasts in the sense that clarification implies engaging learners to reformulate their own utterance and seek clarification of the meaning in the meantime (Loewen \& Nabei, 2007). This, however, leads to the fact that learners are less likely to notice the purpose of error correction. Moreover, engaging learners in self-correction may require a higher level of comprehension and usage of language, which in turn leads to acquiring the language more effectively.

Relating to L2 and FL learning in general and aspects of speaking in particular, there have been a number of research studies on CF on promoting noticing as being useful to the enhancement of grammar accuracy (Ellis et al., 2006; Sheen, 2007; Li, 2010; Zohrabi \& Ehsani, 2014). CF can also develop learners' spoken accuracy according to the findings revealed in other studies, such as those of Chu (2011) and Chehr Azad et al. (2017). Carried out in different contexts, all studies share the similar findings, namely that CF has a positive effect on improving learners' oral accuracy, which is illustrated by the higher scores in the post-test of the experimental group. Tesnim's study (2019) on the impacts of oral CF on learners' speaking skills shows that the immediate and explicit oral CF is able to affect EFL learners' grammatical development positively, but this is yet to improve the other aspects of their oral English skills, including lexical, phonological resources and fluency. In comparison with groups without feedback, groups provided with recast show better performance, especially in terms of phonological acquisition and mastery (Saito \& Lyster, 2012). Similarly, Zakian (2021) maintained that recasts significantly affect the speaking accuracy and willingness to communicate of Iranian EFL students.

In general, extensive research in CF has strongly supported its role in L2 acquisition in general and linguistic accuracy in particular in a focus on form instructional setting by means of drawing learners' attention to the linguistic gap (Ellis, 2016). In other words, CF plays a significant role in the L2 and FL acquisition process.

The researcher carried out two observational research studies on the CF and learner uptake in a high school and a university context. The findings of the above two research studies agree with previous findings (Yang, 2009; Simard \& Jean, 2011; Asari, 2017) that recasts predominantly used in the classrooms are the least likely to lead to successful uptake, whereas other types of $\mathrm{CF}$, including elicitation, clarification request and metalinguistic feedback, resulted in a more negotiated form of feedback between the teacher and the learner and therefore resulted in more successful uptake outcomes. The two studies, however, do not reveal the connection between learners' uptake and language acquisition in the long term.

This current study therefore aims to address the effects of explicit CF in the form of explicit correction, metalinguistic feedback and implicit CF in the form of recasts, and clarification requests on learners' oral accuracy with respect to 
grammar, vocabulary and pronunciation in the context of FL acquisition at Hanoi Law University.

\section{Method}

\subsection{Research Design}

This research employed a before-and-after approach to identify the efficacy on learners' oral accuracy of two types of $\mathrm{CF}$, namely explicit $\mathrm{CF}$ in the form of explicit correction and metalinguistic information, and implicit $\mathrm{CF}$ in the form of recasts and clarification requests. It comprised two cross-sectional data collections applied for the two experimental groups and the control one during 48-hour face-to-face class meeting sessions in the second term of the 2020-2021 academic year at Hanoi Law University (HLU). Basing on the pre-test and posttest scores from these groups, the screened data were treated carefully by IBM SPSS statistics application to evaluate the effects of teachers' CF on learners' oral accuracy.

\subsection{Participants}

The study comprising two kinds of participants was conducted as a case study at a university of law in Hanoi. The first type involved in 47 law-major sophomores who were willing to register as subjects of the study and they were classified into three classes. Specifically, 16 students were arranged in one class labelled as the control group (C.G), which received no form of CF, whereas the experimental group was further divided into two subgroups coded as the experimental group 1 (E.G.1) and the experimental group 2 (E.G.2). The experimental group 1 comprised 16 students receiving explicit correction and metalinguistic feedback while the 15 participants of the E.G.2 were provided with recasts and clarification requests. The participants all indicated that they had spent from five years to 12 years, with an average of seven years learning English. Around $73 \%$ of the participants indicated that their studies had been mainly grammar-based at high school whereas the rest had received a mixture of both grammar and communicative instruction.

The second type of sample population included three qualified lecturers of English, with one teacher being assigned to teach the three classes, using different teaching methods for each class, over an eight-week period. The classes consisted of two hours a day of English instruction, and were scheduled for three days a week. The remaining two teachers were invited to implement pretests and post-tests for three classes to ensure the validity of the study.

Concerning the choice of the lecturers, all of them hold master degrees and have more than ten years' experience of teaching English. They were all explained the purpose of this study, which entailed the teaching facilitator being assigned to providing $\mathrm{CF}$ in the two experimental groups and no $\mathrm{CF}$ in the control group.

\subsection{Data collection instrument}

The research instruments entailed a pre-test and a post-test after 48 hours of learning in an English-speaking course to compare and contrast whether there were any changes when teachers used different methodological teaching strategies for each group of students. To measure the progress, all students took 
part in the before-speaking test which was constructed on the B1 Preliminary Speaking Test format ${ }^{1}$ when starting the course. Part 1 involved individual questions being exchanged between teachers and students for two to three minutes. Part 2 required two students to describe two different photos in two to three minutes before they discussed their ideas together in the same amount of time in Part 3. Part 4 included teachers' interaction by giving questions for students to broaden the topic in Part 3 in 2 to 3 minutes. The approximate duration of the speaking test was 12-17 minutes. When completing the 48-hour face-to-face class meeting sessions, the participants took the after-speaking test, which was also adapted from the B1 Preliminary Speaking Test format. The content validity of the before-and-after English speaking tests were validated by three experienced experts on English language testing and assessment before the implementation of the tests.

\subsection{Procedure}

\subsubsection{Data collection}

To ascertain the liability of the research outcome in a pre-test/post-test design, one teacher was in charge of teaching the whole English-speaking skills course for three groups. According to a pre-set teaching methodology, during eight weeks, the three groups experienced different teaching strategies. Specifically, the control received no CF for their errors in all activities whereas the two experimental groups were subject to $\mathrm{CF}$ treatment during speaking activities. However, the $\mathrm{CF}$ types and timing for providing $\mathrm{CF}$ were not the same in two experimental groups. In the experimental group 2, the $\mathrm{CF}$ in the form of recast or clarification was provided immediately following learners' utterance containing spoken errors. In the experimental group 1, the teacher made no correction of students' errors but took notes during the oral activities. At the end of their performance, the teacher clarified their errors, then gave explicit correct forms or provided the whole group with some metalinguistic feedback to promote their attention and recall.

Before beginning the course, all groups took the B1 speaking test run by two separate teachers marking individually first according to the B1 Assessment Scales, then two teachers summated the scores together. After completing a 48hour speaking skills course, two teachers were summoned to carry out the same B1 speaking test with the same procedures as the pre-test exam of this course. Their oral performances in pre-tests and post-tests were audio-recorded for the later collection. The researcher collected the raw data, screened them, and encoded them for the purpose of data analysis using IBM statistics application. One thing noted is that fluency and complexity of the speaking skills are not the focus of this study.

\subsubsection{Data Analysis}

The screened data were handled by IBM SPSS statistics application for the data analysis. To verify the differences and distribution density in the accuracy of grammar, vocabulary, and pronunciation among these participants, descriptive mean and standard deviation were employed. In addition, the paired-sample $\mathrm{T}$

${ }^{1}$ https://cambridge-exams.ch/sites/default/files/b1-preliminary-handbook-2020.pdf 
test was used to compare and contrast the disparities between the scores of before-and-after English speaking tests. To highlight the percentage of errors with reference to grammar, vocabulary and pronunciation in the pre-tests and post-tests among groups, descriptive frequency was used to differentiate these components. For analysing the effectiveness of teachers' CF, ANCOVA was employed to contrast the differences among the control group, experimental group 1, and experimental group 2.

\section{Results and Discussion}

As previously mentioned, the learners' oral accuracy was evaluated regarding grammar, vocabulary and pronunciation. The results, therefore, are described based on the above criteria.

\subsection{Grammar and Vocabulary}

In order to clarify the level of oral accuracy of the participants in the three groups, at the beginning of the course a pre-test was administered to all participants to determine whether their utterances were different regarding grammar and vocabulary accuracy.

Table 1: Descriptive statistics

\begin{tabular}{ll|l|l}
$\begin{array}{l}\text { Dependent Variable: pre-test } \\
\text { Group }\end{array}$ & Mean & Std. Deviation & $\mathbf{N}$ \\
\hline Control group (C.G) & 2.56 & .964 & 16 \\
\hline Experimental group 1 (E.G.1) & 2.50 & .966 & 16 \\
\hline Experimental group 2 (E.G.2) & 2.60 & 1.056 & 15 \\
\hline Total & 2.55 & .974 & 47 \\
\hline
\end{tabular}

The descriptive statistics for the three groups in the pre-tests are shown in Table 1. The data show that there was not much difference in the accurate use of grammar and vocabulary of the control group $(M=2.56)$, the experimental group $1(M=2.50)$, and the experimental group $2(M=2.60)$. The differences were too small to be significant. Participants in both the control group $(S D=0.964)$ and the experimental group $1(S D=0.966)$ were at fairly equal individual levels of grammar and vocabulary proficiency in their oral production whereas there was a slightly bigger difference in the individual participants' grammar performance $(S D=1.056)$

As is illustrated in Table 2, the p-value of the participants' post-test was less than the confidence interval $(p<0.05)$. The statistics reaffirmed the hypothesis that the groups performed differently in the post-tests. 
Table 2. Tests of between-subjects effects

Dependent Variable: Pre-test

\begin{tabular}{|c|c|c|c|c|c|c|}
\hline Source & $\begin{array}{lr}\text { Type } & \text { III } \\
\text { Sum } & \text { of } \\
\text { Squares } & \\
\end{array}$ & df & $\begin{array}{l}\text { Mean } \\
\text { Square } \\
\end{array}$ & $\mathbf{F}$ & Sig. & $\begin{array}{l}\text { Partial } \\
\text { Squared }\end{array}$ \\
\hline $\begin{array}{l}\text { Corrected } \\
\text { Model }\end{array}$ & $32.505^{\mathrm{a}}$ & 5 & 6.501 & 23.987 & .000 & .745 \\
\hline Intercept & 2.956 & 1 & 2.956 & 10.907 & .002 & .210 \\
\hline Student & 1.416 & 2 & .708 & 2.612 & .086 & .113 \\
\hline Post-test & 32.377 & 1 & 32.377 & 119.461 & .000 & .744 \\
\hline $\begin{array}{l}\text { Student } \\
\text { post-test }\end{array}$ & .030 & 2 & .015 & .055 & .946 & .003 \\
\hline Error & 11.112 & 41 & .271 & & & \\
\hline Total & 350.000 & 47 & & & & \\
\hline $\begin{array}{l}\text { Corrected } \\
\text { Total }\end{array}$ & 43.617 & 46 & & & & \\
\hline
\end{tabular}

a. $\mathrm{R}$ Squared $=.745$ (Adjusted $\mathrm{R}$ Squared $=.714)$

Table 3: Paired samples statistics

\begin{tabular}{ll|l|l|l|l} 
& Mean & $\mathbf{N}$ & Std. Deviation & Std. Error Mean \\
\hline Pair 1 & Pre-test C.G & 2.56 & 16 & .964 & .241 \\
\cline { 2 - 6 } & Post-test C.G & 2.63 & 16 & .806 & .202 \\
\hline \multirow{2}{*}{ Pair 2} & Pre-test E.G.1 & 2.50 & 16 & .966 & .242 \\
\cline { 2 - 6 } & Post-test E.G.1 & 4.19 & 16 & .750 & .188 \\
\hline \multirow{2}{*}{ Pair 3} & Pre-test E.G.2 & 2.60 & 15 & 1.056 & .273 \\
\cline { 2 - 6 } & Post-test E.G.2 & 3.53 & 15 & .834 & .215 \\
\hline
\end{tabular}

Table 4: Paired-sample T test for three groups

\begin{tabular}{|c|c|c|c|c|c|c|c|c|c|}
\hline & & Paired & differenc & & & & & & \\
\hline & & Mean & $\begin{array}{l}\text { Std. } \\
\text { Deviati } \\
\text { on }\end{array}$ & $\begin{array}{l}\text { Std. } \\
\text { Error } \\
\text { Mean }\end{array}$ & $\begin{array}{l}\text { 95\% Co } \\
\text { Interval } \\
\text { Differe } \\
\text { Lower }\end{array}$ & $\begin{array}{l}\text { nfidence } \\
\text { of the } \\
\text { cee } \\
\text { Upper }\end{array}$ & $t$ & $\mathrm{df}$ & $\begin{array}{l}\text { Sig. (2- } \\
\text { tailed) }\end{array}$ \\
\hline Pair 1 & $\begin{array}{l}\text { Pre-test C.G - } \\
\text { post-test C.G }\end{array}$ & -.063 & .443 & .111 & -.298 & .173 & -.565 & 15 & .580 \\
\hline Pair 2 & $\begin{array}{l}\text { Pre-test E.G.1 } \\
-\quad \text { post-test } \\
\text { E.G.1 }\end{array}$ & -1.688 & .479 & .120 & -1.943 & -1.432 & -14.100 & 15 & .000 \\
\hline Pair 3 & $\begin{array}{l}\text { Pre-test E.G.2 } \\
-\quad \text { post-test } \\
\text { E.G.2 }\end{array}$ & -.933 & .594 & .153 & -1.262 & -.605 & -6.089 & 14 & .000 \\
\hline
\end{tabular}

Tables 3 and 4 depict the results of the post-tests in comparison with the pretests. As can be seen, there was a major change in the learners' oral performance regarding the grammar and vocabulary aspects of the two experimental groups with the mean of 4.19 and 3.53, respectively in comparison with the mean of their pre-tests $(M=2.50 ; M=2,60)$. Within the two experimental groups, the effect of CF on learners' usage of grammar and vocabulary also differs. The mean statistic showed that the participants provided with explicit correction and 
metalinguistic feedback performed much better than those provided with recasts and clarification requests. This means that explicit CF led to a more significant improvement in grammar and vocabulary accuracy than the implicit CF. Although it is clear that both types of CF proved to be useful in developing learners' error-free lexical sentences, explicit CF helped the majority of learners to reformulate or enrich their appropriate vocabulary knowledge more than the implicit CF did. Meanwhile, although the mean of the control group in the posttest was higher than that of the pre-test, the rate was not considered to be significant $(\mathrm{M}=2.63 ; \mathrm{sig}=0.580$, but slightly higher than the confidence interval $(p>0.05)$.

This result further strengthened the positive effect of CF on the learners' acquisition of grammatical and lexical resources. Indeed, explicit correction and the prompts such as metalinguistic feedback proved to be much more effective in helping the students produce accurate grammatical utterances because those CF utterances offered them the opportunity to notice the error they had made as well as the use of appropriate grammar rules. As a result, participants did not commit the same errors in their later utterances, thus they were able to produce the correct target structure. This study shared similar findings with previous studies conducted by Koşar and Bedir (2014), and Zohrabi and Ehsani (2014) in the sense that CF promotes grammar acquisition.

\subsection{Pronunciation}

In terms of pronunciation in oral speaking, Table 5 indicates the similar situation in grading pronunciation as grammar and vocabulary aspects. There was an insignificant difference in the pre-test results of the three groups participating in the study with the total mean of 2.19. Notwithstanding, the grade of pronunciation proficiency of learners in the control group and the experimental groups provided with implicit CF varied greatly from learner to learner (SD = 1.109; 1.100 respectively). In other words, in those groups some students were good at pronunciation whereas some were much worse. Examining the participants' scores of the post-tests, the data in Tables 6 and 7 confirm similar results in the grammar and vocabulary sections. Specifically, there was a marked improvement in the participants' pronunciation in the groups with both explicit and implicit CF.

Table 5: Descriptive statistics

Dependent Variable: pre-test

\begin{tabular}{ll|l|l} 
Group & Mean & Std. Deviation & N \\
\hline C.G & 2.19 & 1.109 & 16 \\
\hline E.G.1 & 2.13 & .957 & 16 \\
\hline E.G.2 & 2.27 & 1.100 & 15 \\
\hline Total & 2.19 & 1.055 & 47 \\
\hline
\end{tabular}


Table 6: Paired samples statistics

\begin{tabular}{lll|l|l|l} 
& & & & $\begin{array}{l}\text { Std. } \\
\text { Deviation }\end{array}$ & $\begin{array}{l}\text { Std. } \\
\text { Error } \\
\text { Mean }\end{array}$ \\
\hline Pair 1 & Pre-test C.G - post-test C.G & 2.19 & 16 & 1.109 & .277 \\
\cline { 2 - 7 } & Pre-test E.G.1 - post-test E.G.1 & 2.63 & 16 & 1.088 & .272 \\
\hline \multirow{2}{*}{ Pair 2} & Pre- E.G.2 - post-test E.G.2 & 2.13 & 16 & .957 & .239 \\
\cline { 2 - 7 } & Pre-test C.G - post-test C.G & 3.75 & 16 & .856 & .214 \\
\hline \multirow{2}{*}{ Pair 3} & Pre-test E.G1 - post-test E.G1 & 2.27 & 15 & 1.100 & .284 \\
\cline { 2 - 7 } & Pre-test E.G2 - post-test E.G2 & 3.40 & 15 & .737 & .190 \\
\hline
\end{tabular}

Table 7: Paired samples test

\begin{tabular}{|c|c|c|c|c|c|c|c|c|c|}
\hline \multicolumn{7}{|c|}{ Paired differences } & \multirow{3}{*}{ 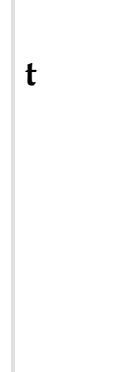 } & \multirow[t]{3}{*}{ df } & \multirow[t]{3}{*}{$\begin{array}{l}\text { Sig. (2- } \\
\text { tailed) }\end{array}$} \\
\hline & & \multirow[b]{2}{*}{ Mean } & \multirow{2}{*}{$\begin{array}{l}\text { Std. } \\
\text { Deviation }\end{array}$} & \multirow{2}{*}{$\begin{array}{l}\text { Std. Error } \\
\text { Mean }\end{array}$} & \multicolumn{2}{|c|}{$\begin{array}{l}95 \% \\
\text { Confidence } \\
\text { Interval of the } \\
\text { Difference }\end{array}$} & & & \\
\hline & & & & & Lower & Upper & & & \\
\hline Pair 1 & $\begin{array}{l}\text { Pre-test C.G } \\
\text { Post-test C.G }\end{array}$ & - - -.438 & .512 & .128 & -.711 & -.164 & -3.416 & 15 & .004 \\
\hline Pair 2 & $\begin{array}{l}\text { Pre-test E.G.1 } \\
\text { Post-test E.G.1 }\end{array}$ & --1.625 & .500 & .125 & -1.891 & -1.359 & -13.000 & 15 & .000 \\
\hline Pair 3 & $\begin{array}{l}\text { Pre-test E.G.2 } \\
\text { Post-test E.G.2 }\end{array}$ & --1.133 & .640 & .165 & -1.488 & -.779 & -6.859 & 14 & .000 \\
\hline
\end{tabular}

In terms of the rate of errors, the following Tables 8, 9 and 10 indicate the increase of error-free utterances in grammatical, lexical and phonological items in the pre-test and post-tests of the three groups in the study.

As clearly illustrated in Table 7, after an eight-week course, in all of the categories the number of errors committed by learners in the control group was reduced. The percentage of grammatical errors in the pre-test and post-test was $81.3 \%$ and $56.3 \%$; that of lexical errors was $87.5 \%$ and $68.8 \%$; while the phonological percentage of errors was $87.5 \%$ and $62.5 \%$, respectively. 
Table 8: Percentage of errors in the pre-test and post-test of the control group

\begin{tabular}{|c|c|c|c|c|c|c|}
\hline & & & Frequency & $\begin{array}{l}\text { Per } \\
\text { cent }\end{array}$ & $\begin{array}{l}\text { Valid } \\
\text { Per cent }\end{array}$ & $\begin{array}{l}\text { Cumulative } \\
\text { Per cent }\end{array}$ \\
\hline Grammar & Valid & $\begin{array}{l}\text { No } \\
\text { error }\end{array}$ & 3 & 18.8 & 18.8 & 18.8 \\
\hline \multirow[t]{2}{*}{ Pre-test } & & Error & 13 & 81.3 & 81.3 & 100.0 \\
\hline & & Total & 16 & 100.0 & 100.0 & \\
\hline \multirow[t]{3}{*}{ Post-test } & Valid & $\begin{array}{l}\text { No } \\
\text { error }\end{array}$ & 7 & 43.8 & 43.8 & 43.8 \\
\hline & & Error & 9 & 56.3 & 56.3 & 100.0 \\
\hline & & Total & 16 & 100.0 & 100.0 & \\
\hline Vocabulary & Valid & $\begin{array}{l}\text { No } \\
\text { error }\end{array}$ & 2 & 12.5 & 12.5 & 12.5 \\
\hline \multirow[t]{2}{*}{ Pre-test } & & Error & 14 & 87.5 & 87.5 & 100.0 \\
\hline & & Total & 16 & 100.0 & 100.0 & \\
\hline \multirow[t]{3}{*}{ Post-test } & Valid & $\begin{array}{l}\text { No } \\
\text { error }\end{array}$ & 5 & 31.3 & 31.3 & 31.3 \\
\hline & & Error & 11 & 68.8 & 68.8 & 100.0 \\
\hline & & Total & 16 & 100.0 & 100.0 & \\
\hline Pronunciation & Valid & $\begin{array}{l}\text { No } \\
\text { error }\end{array}$ & 2 & 12.5 & 12.5 & 12.5 \\
\hline \multirow[t]{2}{*}{ Pre-test } & & Error & 14 & 87.5 & 87.5 & 100.0 \\
\hline & & Total & 16 & 100.0 & 100.0 & \\
\hline \multirow[t]{3}{*}{ Post-test } & Valid & $\begin{array}{l}\text { No } \\
\text { error }\end{array}$ & 6 & 37.5 & 37.5 & 37.5 \\
\hline & & Error & 10 & 62.5 & 62.5 & 100.0 \\
\hline & & Total & 16 & 100.0 & 100.0 & \\
\hline
\end{tabular}

Table 9 shows the enhancement in the use of grammar, vocabulary and pronunciation skills in learners' speech in the experimental group with explicit correction and metalinguistic feedback. Achieving higher scores, learners indicated their performance with a few errors, decreasing from $75 \%$ in the pretest to $18.8 \%$ in the post-test for grammatical errors, from $75 \%$ to $31.3 \%$ for lexical errors and $81.3 \%$ to $31.3 \%$ in phonological errors. This group showed the most improvement compared with the two other groups. This confirmed the results of other previous studies (Dabaghi \& Basturkmen, 2009; Tavakoli \& Zarrinabadi, 2016) in which explicit CF was more effective than implicit CF.

Table 9: Percentage of errors in the pre-test and post-test of the experimental group 1 with explicit correction and metalinguistic feedback

\begin{tabular}{|c|c|c|c|c|c|c|}
\hline & & & Frequency & Per cent & $\begin{array}{l}\text { Valid Per } \\
\text { cent }\end{array}$ & $\begin{array}{l}\text { Cumulative } \\
\text { Per cent }\end{array}$ \\
\hline Grammar & Valid & $\begin{array}{l}\text { No } \\
\text { error }\end{array}$ & 4 & 25.0 & 25.0 & 25.0 \\
\hline \multirow[t]{2}{*}{ Pre-test } & & Error & 12 & 75.0 & 75.0 & 100.0 \\
\hline & & Total & 16 & 100.0 & 100.0 & \\
\hline \multirow[t]{3}{*}{ Post-test } & Valid & $\begin{array}{l}\text { No } \\
\text { error }\end{array}$ & 13 & 81.3 & 81.3 & 81.3 \\
\hline & & Error & 3 & 18.8 & 18.8 & 100.0 \\
\hline & & Total & 16 & 100.0 & 100.0 & \\
\hline
\end{tabular}




\begin{tabular}{lllllll}
\hline Vocabulary & Valid & $\begin{array}{l}\text { No } \\
\text { error }\end{array}$ & 4 & 25.0 & 25.0 & 25.0 \\
Pre-test & & $\begin{array}{l}\text { Error } \\
\text { Total }\end{array}$ & 12 & 75.0 & 75.0 & 100.0 \\
& & 16 & 100.0 & 100.0 & \\
\hline Post-test & Valid & No & 11 & 68.8 & 68.8 & 68.8 \\
& & error & & & & \\
& & Error & 5 & 31.3 & 31.3 & 100.0 \\
& & Total & 16 & 100.0 & 100.0 & \\
\hline Pronunciation & Valid & No & 3 & 18.8 & 18.8 & 18.8 \\
& & error & & & & \\
Pre-test & & Error & 13 & 81.3 & 81.3 & 100.0 \\
& Total & 16 & 100.0 & 100.0 & \\
\hline Post-test & Valid & $\begin{array}{l}\text { No } \\
\text { error }\end{array}$ & 11 & 68.8 & 68.8 & 68.8 \\
& & Error & 5 & 31.3 & 31.3 & 100.0 \\
& & Total & 16 & 100.0 & 100.0 &
\end{tabular}

As it is reflected in Table 9, the students in the experimental group with recasts and clarification requests outperformed in the post-test in comparison with the pre-test, as shown by the increase in the number of students who did not commit errors in terms of grammar, vocabulary or pronunciation, accounting for more than $50 \%$ in average.

Table 10: Percentage of errors in the pre-test and post-test of the experimental group 2 with recasts and clarification requests

\begin{tabular}{|c|c|c|c|c|c|c|}
\hline & & & Frequency & Per cent & $\begin{array}{l}\text { Valid Per } \\
\text { cent }\end{array}$ & $\begin{array}{l}\text { Cumulative } \\
\text { Per cent }\end{array}$ \\
\hline \multirow{3}{*}{$\begin{array}{l}\text { Grammar } \\
\text { Pre-test }\end{array}$} & Valid & No error & 4 & 26.7 & 26.7 & 26.7 \\
\hline & & Error & 11 & 73.3 & 73.3 & 100.0 \\
\hline & & Total & 15 & 100.0 & 100.0 & \\
\hline \multirow[t]{3}{*}{ Post-test } & Valid & No error & 9 & 60.0 & 60.0 & 60.0 \\
\hline & & Error & 6 & 40.0 & 40.0 & 100.0 \\
\hline & & Total & 15 & 100.0 & 100.0 & \\
\hline Lexical & Valid & No error & 3 & 20.0 & 20.0 & 20.0 \\
\hline \multirow[t]{2}{*}{ Pre-test } & & Error & 12 & 80.0 & 80.0 & 100.0 \\
\hline & & Total & 15 & 100.0 & 100.0 & \\
\hline \multirow[t]{3}{*}{ Post-test } & Valid & No error & 8 & 53.3 & 53.3 & 53.3 \\
\hline & & Error & 7 & 46.7 & 46.7 & 100.0 \\
\hline & & Total & 15 & 100.0 & 100.0 & \\
\hline Pronunciation & Valid & No error & 2 & 13.3 & 13.3 & 13.3 \\
\hline \multirow[t]{2}{*}{ Pre-test } & & Error & 13 & 86.7 & 86.7 & 100.0 \\
\hline & & Total & 15 & 100.0 & 100.0 & \\
\hline \multirow[t]{4}{*}{ Post-test } & Valid & No error & 7 & 46.7 & 50.0 & 50.0 \\
\hline & & Error & 7 & 46.7 & 50.0 & 100.0 \\
\hline & & Total & 14 & 93.3 & 100.0 & \\
\hline & Missing & System & 1 & 6.7 & & \\
\hline
\end{tabular}

In the two experimental groups the rate of errors in the participants' speech in the post-test improved markedly after they had received the teacher's CF in the 
form of clarification requests, recasts, metalinguistic feedback and explicit correction during the class activities.

This result implies that EFL students seem to gain an obvious benefit from both immediate and delayed CF delivered by their teacher as they showed remarkable progress in their oral accuracy relating to grammar, vocabulary and pronunciation. This also confirms the hypothesis that $\mathrm{CF}$ treatment means that leaners are more likely to take note of the teacher's correction; thus, it is useful to language acquisition.

One interesting finding in this study is that even for phonological errors, implicit $\mathrm{CF}$ in the form of recast and clarification requests is extremely beneficial. Although the teacher did not provide the overt correction or metalinguistic information directly, the learners could nevertheless notice the deficiency in their pronunciation and reformulate it correctly. Those findings are contrary to Tesnim's study (2019), which states that CF failed to improve learners' pronunciation.

In general, the research questions on the effects of CF on learners' English oral accuracy were answered depending on the presence or absence, types and timing of the CF. The descriptive statistics indicated that there were differences between pre-test and post- test results in all three groups' performance. In particular, the experimental group's accuracy levels were much higher than those of the control groups. This confirmed that CF plays a crucial role in language acquisition as stated in previous studies (Ammar \& Spada, 2006; Ellis et al., 2006; Li, 2010; Sheen, 2007; Zohrabi \& Ehsani, 2014). In this context, CF developed learners' spoken accuracy, which was in line with the findings by Chehr Azad et al. (2017), Chu (2011), and Tesnim (2019).

Statistics of this study strongly support Schmidt's (2001) hypothesis that CF in general and negative feedback in particular assists learners to notice the difference between inter-language forms and target language forms, which in turn results in facilitating their second language acquisition process. However, Schmidt (2001, p.13) also stated that "noticing itself does not result in acquisition" and "learners have to consciously pay attention to or notice input in order for input to become intake for L2 learning". This confirmed that providing $\mathrm{CF}$, a crucial method for drawing learners' attention to their errors, encourages learners to become aware of theirs, thus fostering inter-language development. Notwithstanding, that how effective it is depends on the learners' levels of consciousness.

In the two experimental groups, the rate of grammatical, lexical, and phonological accuracy of the experimental group provided with explicit $\mathrm{CF}$ was higher than that of the experimental group provided with implicit CF. However, such distinctions were not demonstrably clear enough to be statistically significant, particularly for measuring phonological development. This result supported Kim and Mathes' study (2001), which indicated few significant differences between the scores of the groups receiving explicit and implicit CF. The study also shares the similar findings with those of Rahimpour et al. (2012) 
who aimed to identify the impacts of intensive and extensive focus on form strategies on EFL learners' oral accuracy. Rahimpour et al. (2012) demonstrated that the performance of the two groups in the oral narrative task was nearly the same. The findings are, in particular, similar to those in the study by Chehr Azad et al. (2017) which showed insignificant variance in the number of errorfree oral utterances by the participants provided with different $\mathrm{CFs}$.

\section{Conclusion}

Overall, the present study aimed to investigate the effects of CF on oral English accuracy, and based on the findings, important conclusions could be drawn.

Firstly, CF has a significant effect on improving oral English accuracy regarding grammar, vocabulary and pronunciation as indicated by the higher scores of the two experimental groups compared with those of the control group. Most of the students in the experimental groups demonstrated their enhancement in oral accuracy by committing fewer errors and successfully reformulating the correct target language. In other words, both immediate implicit $\mathrm{CF}$ and delayed explicit CF proved to have a positive impact on the reinforcement of the participants' oral accuracy. This was indicated by the decrease in the rate of errors in their later utterances after receiving teacher's CF during the class activities in the course.

Secondly, the explicit $\mathrm{CF}$, including explicit correction and metalinguistic feedback, influences English oral accuracy more positively than implicit CF. Provided with explicit $\mathrm{CF}$ at the end of their utterance, learners find it easier to be aware of their errors, transforming the input to becoming intake for L2 learning than being provided with immediate implicit CF. Explicit CF therefore proves to have a significant effect on the L2 acquisition process. However, it should be noted that although CF significantly influences oral accuracy, the efficacy of the two types of CF is not significant. Even more interestingly, when examining the scores relating to different aspects of oral accuracy of each participant in the two experimental groups, it was revealed that both types of CF seem to be more effective for learners with lower mean scores as they can be made aware of their errors and improve their accuracy. Learners with higher mean scores seem to focus more on improving their oral fluency and complexity than their oral accuracy.

The current study, however, has several limitations. One of them is related to the duration of the research. This experimental research was conducted in only eight weeks, which was assumed to be not long enough to measure CF efficiency for long-term language acquisition. Another limitation concerns the time when the post-test was conducted. Specifically, in this study, the participants were required to take the immediate post-test after the course whereas the delayed post-test was not carried out, the results, to some extent, are less likely to reflect the prolonged effect of CFs. Moreover, the participants in this study were at a low intermediate level, thus the findings cannot be generalised to students at different levels of proficiency. The last limitation concerns the scope of the study. This study only measured the effects of CF on learners' oral accuracy whereas fluency and complexity - the two remaining aspects of speaking skills 
were not evaluated. Consequently, further research should be carried over a longer period, focusing on all aspects of speaking with a population at different levels of English proficiency in order to address these limitations.

\section{References}

Ammar, A., \& Spada, N. (2006). One size fits all? Recasts, prompts and L2 learning. Studies in Second Language Acquisition, 28, 543-574. https://www.researchgate.net/publication/232021519_One_size_fits_all_Recast s_prompts_and_L2_learning

Asari, Y. (2017). Salience-enhanced recasts and their effects on learners' production of uptake and modified output. Journal of Pan-Pacific Association of Applied Linguistics, 21, 65-84. https://files.eric.ed.gov/fulltext/EJ1155915.pdf

Baleghizadeh, S., \& Dadashi, M. (2011). The effect of direct and indirect corrective feedback on students' spelling errors. Profile Issues in Teachers` Professional Development, 13(1),

129-137. https://www.researchgate.net/publication/262444891_The_Effect_of_Direct_a nd_Indirect_Corrective_Feed back_on_Students\%27_Spelling_Error.

Brown, D. (2014). The type and linguistic foci of oral corrective feedback in the L2 classroom: A meta-analysis. Language Teaching Research 20(4), 436-458. https://doi.org/10.1177/1362168814563200

Brown, D. (2016). The type and linguistic foci of oral corrective feedback in the L2 classroom: Ameta-analysis. Language Teaching Research, 20(4), 436-458.

Chehr Azad, M. H., Farrokhi, F., \& Zohrabi, M. (2017). The effects of the corrective feedback on Iranian EFL learners' speaking accuracy and breakdown fluency. Journal of Language Horzons, Alzabra University 1(2), 107-129. https://lghor.alzahra.ac.ir/article_3188_b82001717d99bbb0da672cfceb85629ca.pd $\mathrm{f}$

Chu, R. (2011). Effects of teacher's corrective feedback on accuracy in the oral English of English major college students. Theory and Practice in Language Studies, 1(5), 454459.

Dabaghi, A., \& Basturkmen, H. (2009). The effectiveness of implicit and explicit error correction on learners' performance. System 37, 82-98.

Dam, L. M. (2016). The effectiveness of indirect written corrective feedback as perceived by teachers and students of a public university in Vietnam. International Journal of Education and Literacy Studies, 6(4), 152-162. http://dx.doi.org/10.7575/aiac.ijels.v.6n.4p.152

Ellis, R. (2003). Task-based language learning and teaching. Oxford University.

Ellis, R. (2016). Focus on form: A critical review. Language Teaching Research 20(3), 405-428 https://doi.org/10.1177/1362168816628627

Ellis, R., \& Barkhuizen, G. (2005). Analysing learner language. Oxford University Press.

Ellis. R., Loewen, S., \& Erlam, R. (2006). Implicit and explicit corrective feedback and the acquisition of L2 grammar. Studies in Second Language Acquisition, 28, 339-358. http://www.jstor.org/stable/44487071

Gower, R., Phillips, D., \& Walters, S. (2005). Teaching practice handbook. Macmillan Education.

Ha, X. V. (2017). Primary EFL teachers' oral corrective feedback in Vietnam: Beliefs and practices. [Master's thesis, Macquarie University, NSW, Australia]. https://www.researchonline.mq.edu.au/vital/access/manager/Repository/m q:70822

Ha, X. V., Murray, J., \& Riazi, A.M. (2021). High school EFL students' beliefs about oral 
corrective feedback: The role of gender, motivation and extraversion. Studies in Second Language Learning and Teaching, 11(2), 235-264.

Ha, X. V., \& Murray, J. C. (2020). Corrective feedback: Beliefs and practices of Vietnamese primary EFL Teachers [Advanced online publication]. Language Teaching Research.

Ha, X. V., \& Nguyen, L. T. (2021). Targets and sources of oral corrective feedback in English as a foreign language classrooms: Are students' and teachers' beliefs aligned? Frontiers in Psychology, 12, 697160.

Le, H. M. (2014). The role of corrective feedback in Vietnamese High school students' writing. Ho Chi Minh Open University Journal of Science, 3(1), 61-69.

Hosseiny, M. (2014). The role of direct and indirect written corrective feedback in improving Iranian EFL students' writing skill. Procedia-Social and Behavioural Sciences, 98, 668-674. https://doi.org/10.1016/j.sbspro.2014.03.466

Housen, A., \& Kuiken, F. (2009). Complexity, accuracy and fluency in second language acquisition. Applied Linguistics, 30(4), 461-473.

Kim, H., \& Mathes, G. (2001). Explicit vs. implicit corrective feedback. Korea TESOL Journal, 4, 1-15.

Koşar, G., \& Bedir, H. (2014). Strategies-based instruction: A means of improving adult EFL learners' speaking skills. International Journal of Language Academy, 2(3). http:/ / oaji.net/articles/2014/505-1411382239.pdf

Li, H., \& Iwashita, N. (2021). The role of recasts and negotiated prompts in an FL learning context in China with non-English major university students. Language Teaching Research, 25(2), 209-233. https:/ / doi.org/10.1177/1362168819839727

Li, S. (2010). The effectiveness of corrective feedback in SLA: A meta-analysis. Language Learning, 60, 309-365. http://doi.org/10.1111/j.1467-9922.2010.00561.x

Li, S. (2014). Key concepts in ELT. Oral corrective feedback. ELT Journal 68(2), 196-198.

Li, S., \& Vuono, A. (2019). Twenty-five years of research on oral and written corrective feedback in System. System 84, 93-109.

Lightbown, P. M., \& Spada, N. (2003). How languages are learned? Oxford University press.

Lyster, R., \& Mori, H. (2006). Interactional feedback and instructional counterbalance. Studies in Second Language Acquisition, 28, 269-300. https://doi.org/10.1017/S0272263106060128

Lyster, R., Saito, K., \& Sato, M. (2013). Oral corrective feedback in second language classrooms. Language Teaching, $46 \quad$ (1), $1-40$. http://doi.org/10.1017/S0261444812000365

Loewen, S., \& Nabei, T. (2007). Measuring the effects of oral corrective feedback on L2 knowledge. In A. Mackey (Ed.), Conversational interaction and second language acquisition: A series of empirical studies (361-377). Oxford University Press.

Mujtaba, S. M., Parkash, R., \& Nawaz, M. W. (2020). Do indirect coded corrective feedback and teachers' short affective comments improve the writing performance and learners'uptake? Reading \& Writing Quarterly, 36(1), 34-47. https:// doi.org/10.1080/10573569.2019.1616638

Tesnim, O. (2019). Oral corrective feedback and its impact on learners' speaking skills: Tunisian EFL students as a case study. International Journal of Language and Linguistics, 7(3), 138-149. http://doi.org/10.11648/j.ijll.20190703.15

Pham, N. L., \& Iwashita N. (2018). Using corrective feedback on writing to enhance Vietnamese learners' autonomy. In A. Burns, \& J. Siegel (Eds.), International perspectives on teaching the four skills in ELT. International perspectives on 
English language teaching. Palgrave Macmillan. https://doi.org/10.1007/9783-319-63444-9_15

Pham, T. X., \& Pham, H.T. (2018). Oral corrective feedback in ESL/EFL classrooms: Classification models. VNU Journal of Foreign Studies, 35 (5), 40-48.

Rahimpour, M., Salimi, A., \& Farrokhi, F. (2012). The effect of planned vs. unplanned form-focused strategies on L2 learners' accuracy in oral task performance. Education Research Journal, 2, 247-252.

Saito, K., \& Lyster, R. (2012). Effects of form-focused instruction and corrective feedback on L2 pronunciation development of / $\mathrm{I} /$ by Japanese learners of English. Language Learning, 62, 595-633. http:// doi.org/10.1111/j.1467-9922.2011.00639.x

Savignon, J. S. (2006). Beyond communicative language teaching: What's ahead? Journal of Pragmatics, 39(1), pp. 207-220.

Simard, D., \& Jean, G. (2011). An exploration of L2 teachers' use of pedagogical interventions devised to draw L2 learners' attention to form. Language Learning, 61(3), 759-785. https://doi.org/10.1111/ j.1467-9922.2011.00656.x

Schmidt, R. (2001). Attention. In P. Robinson (Ed.), Cognition and second language instruction, 3-32. Cambridge University Press.

Sheen, Y. (2007). The effects of corrective feedback, language aptitude, and learner attitudes on the acquisition of English articles. In A. Mackey (Ed.), Conversational Interaction in Second Language Acquisition: A series of Empirical Studies, 301-322. Oxford: Oxford University Press.

Sheen, Y. (2011). Corrective feedback, individual differences and second language learning. Springer.

Tavakoli, M., \& Zarrinabadi. N. (2018). Differential effects of explicit and implicit corrective feedback on EFL learners' willingness to communicate. Innovation in Language Learning and Teaching, 12(3), 247-259. https://doi.org/10.1080/17501229.2016.1195391

Yang, Y. (2009). Feedback and uptake in Chinese EFL classrooms: In search of instructional variables. The Journal of Asia TEFL, 6(4), 1-22.

Zakian, M. (2021). The effects of recast on the speaking accuracy and willingness to communicate (WTC) of Iranian EFL learners across gender. International Journal of English Language and Translation Studies, 9(1), 75-80.

Zohrabi, K., \& Ehsani, F. (2014). The role of implicit \& explicit corrective feedback in Persian-speaking EFL learners' awareness of and accuracy in English grammar. International Conference on Current Trends in ELT. Procedia Social and Behavioral Sciences, 98, 2018-2024. 